\title{
CONFLICT OF INTEREST IN FEDERAL PROCUREMENT
}

\author{
Harold C. Petrowitz*
}

\section{INTRODUCTION}

The era of big government has thrust sharply into focus the matter of business ethics in transactions between public authorities and those with whom they deal. Open corruption in the federal government has never been condoned by the American public, but the ethics of individual officials have not always been scrutinized as closely as they are today. As government has grown more and more pervasive, standards of conduct for public officials have been pushed ever upward until they now stand at an all time high.

Bribery, and some aspects of dealing in favor of self, have long been outlawed, but it is only recently that legislative and regulatory actions have been taken to strike at some of the more subtle and pernicious aspects of conflict of interest in public office.

Conflict of interest will here be defined as any act or position taken by a public official that places or appears to place the fair and unbiased administration of his public office in substantial conflict with his personal economic interests. ${ }^{1}$ The view is commonly accepted that if the conduct of a public office can sufficiently affect the private economic interests of a government official, his administration of the office for the public good will inevitably be influenced to an unacceptable degree by this conflict between obligation to the public and desire for personal profit. The conclusion necessarily drawn then is that personal economic interests must be separated from the conduct of public office to a sufficient extent so that undue conflict will not occur. It is the purpose of conflict of interest statutes and regulations to erect the barriers needed to achieve this separation.

Bribery of a government official is such a flagrant violation of public trust that

- B.S. 1943, University of Michigan; LL.B. x950, Georgetown University; LL.M. I962, Columbia University. Member of the bars of the Supreme Court of the United States and the District of Columbia. Assistant Professor of Law, University of Denver College of Law. Consultant on government contracts. Author, The Battle over Proprietary Interests in Defense Contracts, California Management Review, Vol. 2, No. I (Fall 1959); SYlLabUs on Government Contract LaW (I96I).

The author gratefully acknowledges the research assistance of Mr. Lawrence Lavers, a student at the University of Denver College of Law, in the preparation of this article.

1 This is essentially the definition adopted in the report, Ass'N of THE BAR of THE CITY of NEW York, Spectal Commttee on the Federal Conflict of INterest Latis, Conflict of Interest and Federal Service 3 (1960) [hereinafter cited as Bar Association Report]. Conflict of interest in its broadest sense can be generated around any two or more opposing interests or obligations that a given person may have. This can happen in almost any area of human activity-social, political, and religious, as well as economic. We are here concerned only with the conflict that can develop between the duty of a government official to his office and the public he is obligated to serve, and his natural desire for personal economic gain. 
it was understandably the first aspect of conflict of interest to be positively outlawed. ${ }^{2}$ Modern concepts of conflict of interest in public office are generally considered to include these additional acts and situations: (a) active participation in any specific governmental action that will substantially affect the personal economic interests of the acting official. The most obvious example of this would be the award of a public contract to a business concern in which the awarding official owns a controlling interest. ${ }^{3}$ More subtle but equally effective would be the exertion of pressure on a prime contractor to subcontract with a concern in which the government official holds a stock interest; (b) special assistance to private persons in their dealings with the government in such a way that an unfair advantage might be given to those assisted or some economic gain might accrue to the government official involved. The prosecution by a government attorney of a claim asserted against the government by a private party is the typical example of this violation. One of the earliest statutes dealing with conflict of interest was aimed specifically at curbing this abuse; $^{4}$ (c) acceptance by a public official of something having economic value from a private person under circumstances that might impair the fair and objective performance of his official duties. The most obvious target of this injunction is pure bribery. The giving of gifts, however, is now considered equally violative of this prohibition. In fact, the sensitivity to this aspect of conflict has now become so well developed that the bestowal of any gratuity that even has the appearance of impairing the objectivity of official action falls within its scope; (d) former public officials should be precluded from assisting private persons with respect to any transactions in which such an official played an active or substantial role while with the government. This problem is analogous to the favoritism abuse discussed in (b) above except that here the assistance occurs after the official has left his government position and pertains to matters over which he exercised a substantial degree of control while holding public office. Post-employment restraints need be imposed only long enough to nullify the unfair advantage resulting from inside information or close personal relationships possessed by the former official. Control of this abuse would lessen the incentive to "pirate" employees from the government for limited purposes; (e) public officials should not be permitted to derive personal economic gain from the use of inside or confidential information to which their government position gives them access. For example, an employee of the agency regulating the assignment of airline routes should not be permitted to use inside information that a lucrative air route is about to be assigned to a particular carrier for the purpose of speculating in the stock of that carrier. On the other hand, the determination as to exactly what

\footnotetext{
${ }^{2}$ A law pertaining to bribery of judges was enacted in 1790 , Rev. Stat. $\$ 5449$ (I875). Until October 23 , 1962, most of the anti-bribery statutes were codified in I8 U.S.C. $\$ \S 201-223$ (1958), the first general prohibition having been enacted in 1853 .

${ }^{3}$ The likelihood of this happening in federal procurement is becoming increasingly remote because of the large number of persons who ordinarily participate in contract actions, the rigid compartmentalization of their duties, and the many stages of review.

1o Stat. I70 (x853), as amended, I8 U.S.C. $\$ 283$ (I958).
} 
information the government official should not be permitted to use for his personal advantage is extraordinarily difficult and not readily amenable to statutory definition. If unreasonable restraints are placed on the use of information, the cure can be worse than the disease.

In addition to these primary areas of conflict of interest, there are several peripheral aspects that are important enough to merit consideration. They include outside employment; ${ }^{5}$ influence peddling; special financial interests; contingent fees; kickbacks; ex parte communications and organizational conflicts. Kickbacks and contingent fees are barred by general statutes, ${ }^{6}$ but the other violations are dealt with only in department and agency regulations or in laws of limited application.

\section{BACKGROUND}

Government has not always been the full time job it is now. During much of the nineteenth century it was common for federal government officials to hold jobs in addition to their official posts. This was true in all branches of the government and was in large measure attributable to the fact that the pay of public officials was very low and the demands of their positions not very great. Most congressmen pursued active law practices and many judges and appointees in the executive branch were engaged in agricultural or professional pursuits in addition to their government duties.

Despite their disadvantages, government jobs were much sought after as rewards for political activity in behalf of elected officials. To the political as well as the military victor belonged the spoils; and the appointment of the political party faithful to federal posts was an important factor in the maintenance of effective political organizations. There was no merit system in the federal service and professional standards were unknown.

Gross abuses resulting from what is now known as conflict of interest soon became evident. During peacetime, they centered around claims against the government which were often prosecuted by congressmen and other high federal officials. In time of war, these abuses took the form of award of government contracts for supplies and services to favorites or personal interests of government officials. The ethics in government service during most of the I80os were deplorably low. ${ }^{7}$

Even during the darkest days, however, efforts were made to curb some of the most flagrant abuses. One of the first general conflict of interest statutes enacted in I853 forbade government officials to assist in the prosecution of claims against the

\footnotetext{
"An outside or second job-referred to in labor circles as "moonlighting"-can often adversely affect the performance of a public official simply by causing excessive demands on his time and energy. There is also the possibility that such outside employment will be so closely related to the government duties of the public official that self-dealing or inappropriate use of confidential information become irresistible temptations.

${ }^{8} 60$ Stat. 37 (1946), as amended, 74 Stat. 740 (1960), 4I U.S.C. $\$ 5$ I (Supp. 1962) (kickbacks); 10 U.S.C. $\$ 2306$ (I958); 63 Stat. 395 (I949), 4I U.S.C. $\$ 254$ (1958) (contingent fees).

${ }^{7}$ For a history of the federal service, see generally PAUL R. VAN RIPER, History OF THE UNITED STATres Civil Service (1958); James G. Randali, The Civil War and Reconstruction (1937).
} 
United States. The criminal sanctions of this and similar laws, coupled with improved procedures in the Court of Claims, did much to eliminate claims abuses. Another statute enacted in $1862^{\circ}$ made it a crime for government officials to receive consideration in connection with the award of contracts, thus striking at the major wartime abuse. ${ }^{10}$

It is noteworthy that when serious problems relating to conflict of interest became evident, statutory efforts were made to correct them, ${ }^{11}$ but this had the result of imposing a "Topsy" effect on such laws. The establishment of the merit system in an organized federal civil service in $1883^{12}$ provided the foundation for the emergence of big government that was to begin in I933. The patchwork of conflict of interest statutes that existed until October 1962 , was totally inadequate for resolving the ethical problems posed by all pervasive government of full time professional experts where standards of conduct must be of the highest order if public confidence is to be maintained. Nor were existing laws well adapted to the strict ethical requirements being laid down by Congress in approving high-level federal appointments and by the courts in recent conflicts cases.

The Supreme Court of the United States has made it clear that a very rigid ethical standard will be applied in situations involving conflict of interest within the federal government. In the famous Dixon-Yates case, ${ }^{13}$ the Court held invalid a contract for construction of a steam generating plant between a power company and the Atomic Energy Commission on the ground that an investment corporation officer then acting as an unpaid consultant for the Bureau of the Budget could have influenced decisions regarding the financing of the project to a sufficient extent so that his employer might have derived a profit. The Court applied an old postCivil War penal disqualification statute ${ }^{14}$ in ruling that the possibility of profit as a

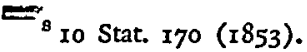

${ }^{\circ}{ }_{2}$ Stat. 577 (1862).

${ }^{10}$ For a full discussion of the other conflict of interest statutes enacted during this period, see Bar Association Report 36-49.

${ }^{11}$ The most glaring exception to this attitude is Congress itself which has displayed a conspicuous lack of enthusiasm for enacting legislation that would truly eliminate conflict of interest problems with respect to itself. Public intolerance of corruption in our federal government is to be contrasted with the situation in some other nations where graft, bribery, and self-dealing among government officials must be accepted as a fact of life.

${ }^{12} 22$ Stat. 403 (1883), known as the Pendleton Act. It is interesting to note that the establishment of a genuine merit system for recruitment of federal employees largely deprived the party system of its primary method of allocating rewards for effort in securing the election of political candidates. No real substitute for this reward has been found. Many policy and confidential federal posts are still appointive but such appointments are now made primarily on the basis of demonstrated ability rather than on the theory of the spoils system. Only in the appointment of certain postmasters does the spoils system survive in anything resembling its original context.

${ }^{20}$ United States v. Mississippi Valley Generating Co., 364 U.S. 520 (r96r).

${ }^{14}$ I8 U.S.C. $\$ 434$ (1958), which stated: "Whoever, being an officer, agent, or member of, or directly or indirectly interested in the pecuniary profits or contracts of any corporation, joint stock company, or association, or of any firm or partnership, or other business entity, is employed or acts as an officer or agent of the United States for the transaction of business, shall be fined not more than $\$ 2,000$ or imprisoned not more than two years, or both." 
result of the conflict in interest was enough to violate the public policy aspect of the law and render the contract invalid $a b$ initio. ${ }^{15}$

The Senate has also made it clear that it does not necessarily agree that what is good for General Motors is good for the country. ${ }^{16}$ Cases in which high government officials have resigned under circumstances involving conflict of interest continue to crop up. Two of the most recent have involved Fred Korth, former Secretary of the Navy, and Robert Baker, Majority Secretary of the United States Senate. ${ }^{17}$ Nor have congressmen themselves been immune from sanction. Former congressmen Frank W. Boykin of Alabama and Thomas F. Johnson of Maryland were recently indicted for violating section $28 \mathrm{I}$ of the Criminal Code by rendering special services to persons outside the government.

\section{The New Legislation}

Recognizing that existing conflicts of interests statutes were inadequate for the enforcement of the high ethical standards of conduct being demanded, Congress, under the prodding of numerous interested groups, most notably the Association of the Bar of the City of New York, completely revised the law relating to many aspects of conflict of interest, and this legislation became effective on January $2 \mathrm{x}, \mathrm{xg} \sigma_{3}$ as Public Law $87-849 .^{18}$ The new law added sections $20 \mathrm{x}-209$ and 218 to chapter eleven of title eighteen of the United States Code, redesignated former sections 214, 215, 217-222 as 210-2I7, eliminated old sections 20I-213, which pertained to various aspects of bribery, by combining them into new section 20x, repealed sections $216,223,282$, 284, 434 and $\mathrm{IgI}_{4},{ }^{19}$ and combined their substance into new sections 204,207 and 208. Old sections $28 \mathrm{r}$ and 283 were partially repealed in so far as they applied to public officials and their substance combined into new sections 203, 204, 205, 207 and 209, but were left standing as they apply to retired regular officers of the armed forces of the United States. ${ }^{20}$

${ }^{15}$ The Dixon-Yates case actually arose when the government cancelled a contract for construction of the power plant because of no further need and the contractor sued for breach of contract damages. One of the main defenses asserted by the government was invalidity of the contract because of conflict of interest even though the statute contained no contract cancellation clause for its violation as did some of the other then existing conflict of interest laws. The Court ignored this technicality and rested its decision on the general public policy issue even though no criminal prosecution had been or ever was initiated as specifically provided by the statute. The Court concluded by holding that, since the government had received no benefit from the contract, there could be no quantum valebat recovery. The contractor, therefore, sustained a loss of approximately \$I.8 million on the transaction.

${ }^{10}$ Hearings Before the Senate Armed Forces Committee on Armed Services, on Nominees Designate: Charles $E$. Wilson, Roger M. Kyes and Others, 83d Cong., Ist Sess. 6-19 (1953). Mr. Wilson, to whom the statement is attributed, was ultimately confirmed as Secretary of Defense but on condition that he divest himself of his stock in General Motors, of which he had been president.

${ }^{17}$ Korth was accused of using official Navy stationery for writing business letters to companies interested in dealings with the government. He resigned without any comment as to these accusations. Baker was accused of outside business dealings and infuence peddling involving certain government agencies. Senate hearings on Baker's multifarious activities have provided interesting television viewing in recent weeks.

${ }^{18} 76$ Stat. $x$ Irg ( 1962$)$, I8 U.S.C.A. $\$ \$ 201-219$ (1963).

${ }^{10}$ Pub. L. No. $87-849$ also repealed section 99 of title 5, U.S. Code, an old post-employment statute that placed a two-year ban on former government employees prosecuting claims which were pending in the department in which they were formerly employed.

${ }_{20}$ Table showing the effect on existing statutes of Pub. L. No. 87-849. 
Section 201 includes all of the general bribery prohibitions of the new law and applies to all public officials in any branch of the federal government including members of Congress. It forbids the transfer of anything of value to a public official or to anyone designated by a public official where the intent of such transfer is to influence an official act, to cause any public official to participate directly or indirectly in fraud or to induce any act or omission violative of the official's lawful duty. The prohibition is directed equally at the person exerting the influence and the public official who solicits or succumbs to the bribe. ${ }^{21}$ The section concludes with an injunction against the giving of anything of value to a public official "for or because of any official act performed or to be performed."22 The first part of the

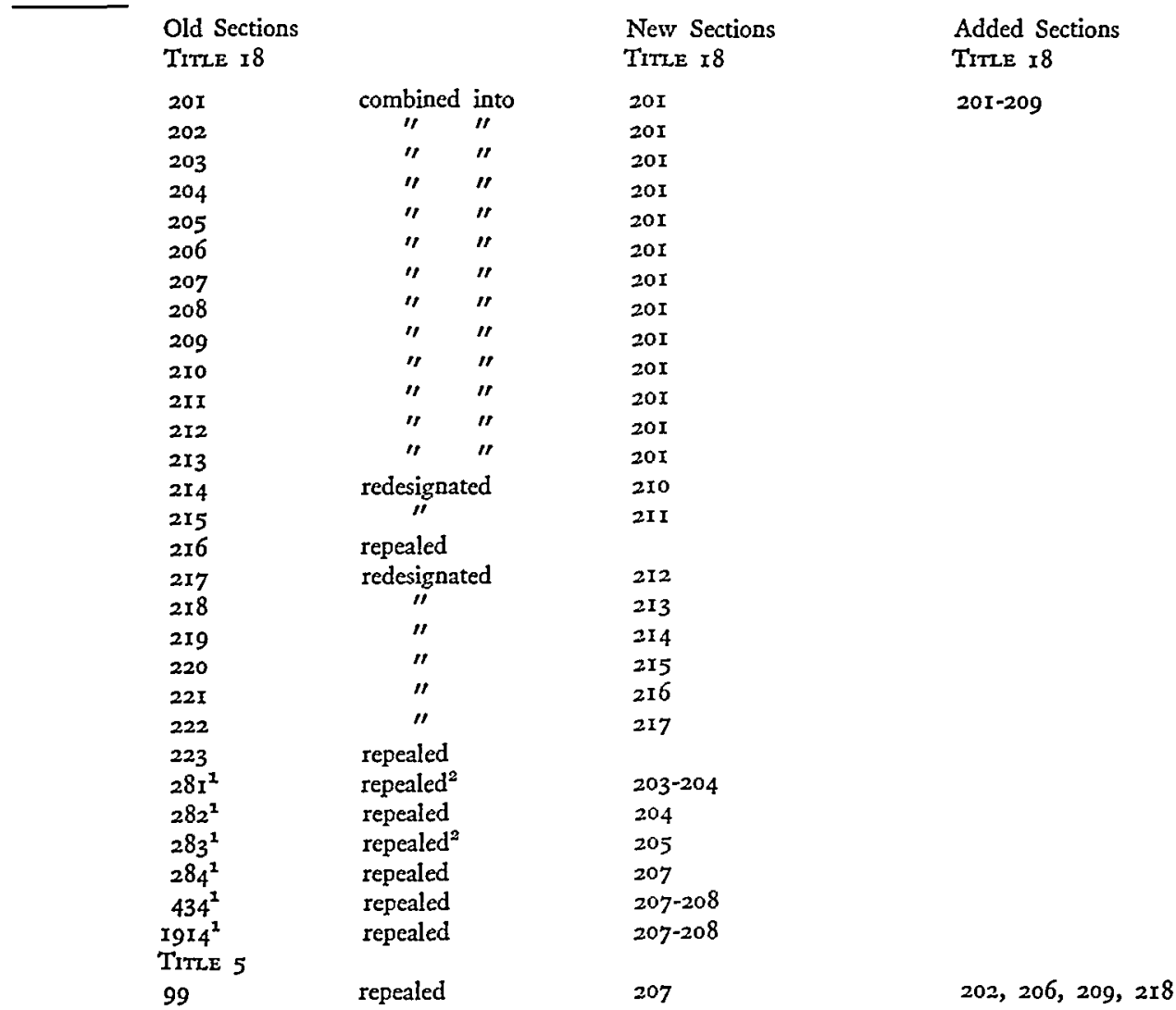

${ }^{22}$ Also prohibited is any similar act intended to influence the testimony of witnesses before courts, Congress, agencies or officers legally authorized to take testimony. The penalties for such attempts to influence official acts, officials, or testimony are severe-a fine not to exceed $\$ 20,000$ or three times the value of the bribe, whichever is greater, or imprisonment for not over fifteen years, or both, and possible, though not mandatory, disqualification from holding any responsible federal office in the future.

${ }^{23}$ This part of the section also applies to testimony of witnesses and carries lesser penalties (fine not exceeding $\$ 10,000$ or imprisonment for not over two years, or both) than those applied to acts specifically intended to exert influence.

${ }^{1}$ The special exemptions to these statutes were retained by the new law as applied to legislative and judicial branches.

Not repealed as applied to regular retired members of the armed forces of the United States. 
section, therefore, applies to acts intended to influence or corrupt, and the second part outlaws the giving of any rewards for official acts performed or to be performed.

The language of section $20 \mathrm{I}$ is sweeping and is specifically designed to prohibit all aspects of bribery, including rewards. The prohibition applies to any attempt to influence, corrupt, or reward regardless of whether the official approached has it within his power or authority to bring about the objective sought. The wording of this part of the section makes it apparent that specific intent must be proved in order to convict the offeror of the thing of value where the objective is to influence an official act, cause the commission of fraud or induce an act or omission in violation of a lawful duty. ${ }^{23}$ Proof of specific intent on the part of the offeror is the element that makes control of bribery under the penal statutes difficult, and it is the existence of intent that distinguishes this aspect of a bribe from a pure gift. The word "intent" is not used with reference to the wrongful act of the recipient or designer of the thing of value (the "bribee," so to speak), nor is it used at all with respect to the giving or receiving of rewards for public acts. It would appear, then, that proof of specific intent may not be required for conviction under these parts of section 20r and there is case law to support this conclusion. ${ }^{24}$ Nevertheless, some evidence linking the thing of value (cause) and the official act or omission (effect) appears necessary in order to secure conviction. Although the language of section 201 appears sufficiently broad to reach every aspect of bribery, it does not forbid the making of or receipt of pure gifts where there is no connection shown between the thing of value and the official act. ${ }^{25}$

\footnotetext{
${ }^{23}$ Numerous cases decided on the basis of similar wording in the superseded bribery action have so held. United States v. Labovitz, 251 F.2d 393 (3d Cir. I958); United States v. Bowler, I83 F. Supp. 237 (D. Maine 1958).

24 Razete v. United States, r99 F.2d 44 (6th Cir. 1952), cert. denied, 344 U.S. 904 (1953). The decision of the court in this case is of more than passing interest because of its interprctation of statutory language very similar to that used in section 20r. Razete, president of a company that obtained a contract with the Air Force under rather dubious circumstances, was convicted of giving a bribe in the form of cash and a radio to a contracting officer of the Air Materiel Command. The contract awarded Razete's Company was for supplies to be used in the Mutual Defense Assistance Program. The statute authorizing this Program contained the following clause (since repealed): "Whoever offers or gives to anyone who is now or in the past two years has been an employee or officer of the United States any commission, payment or gift in connection with the procurement of equipment, materials or scrviccs under this chapter, and whoever, being or having been an employee or officer of the United States in the past two years, solicits, accepts or offers to accept any such commission, payment or gift, shall upon conviction thereof be subject to a fine of not to exceed \$10,000 or imprisonment for not to cxceed three years, or both." 22 U.S.C. 1584 (1952). In upholding the conviction of the federal district court, the court of appeals pointedly noted that, since the wording of the statute departed from the common law description of bribery, it thus created a new statutory crime for conviction of which proof of specific intent was not required. Here it was the offeror who was found guilty of violating the statute, the offeree (the contracting officer) having pleaded guilty. It seems clear that the wording in the latter part of section $20 I$ is subject to the same interpretation.

${ }^{25}$ Chapter II of title 18 also contains some specific prohibitions of bribery in addition to the general prohibition of $\$ 201$. Sections 210 and 211 prohibit the giving or accepting of anything of value for the purpose of obtaining any federal appointive office. Section $2 \mathrm{I} x$ also forbids the payment or collection of anything of value for securing employment with the federal government. Both sections impose criminal sanctions. Sections 212 and 213 make it a crime to bribe a federal bank examiner; $\$ \$ 2 I 4$ and 215 impose criminal penalties for bribery in connection with a Federal Reserve bank loan or discount of commercial
} 
Section 202 defines a new category of federal employee, that of "special Government employee," referred to in sections 203, 205, 207, 208, and 209 of the substantive provisions. A special government employee is an officer or employee of the executive or legislative branches or of any independent federal agency ${ }^{26}$ who is hired to perform duties on a temporary or intermittent basis with or without compensation for not more than I30 days during any period of 365 consecutive days. ${ }^{27}$ The r30 day test applies only prospectively to the duration of the appointment. If it turns out that the employee serves more than I30 days out of 365 , he does not thereby lose his special status. ${ }^{28}$

Special government employees usually consist of consultants, advisers, and other intermittent employees whose duties are not intended to be continuous or of extended duration. The substantive provisions of the new conflict of interest legislation appropriately recognize that individuals filling these unusual positions should receive different treatment from that accorded regular federal employees. A representative of a non-governmental activity who is requested to appear before a government department or agency and is not paid a salary by the government is not an official or employee of the government-either regular or special-and the prohibitions of this statute do not apply to him. ${ }^{29}$

Section 203 imposes a broad prohibition on the solicitation or receipt of outside compensation for services rendered by a government official or his designee before any United States department, agency, or commission in behalf of private parties with respect to any transaction in which the federal government has a direct or sub-

paper; $\$ 216$ prohibits the giving or receiving of commissions or gifts in connection with federal farm loans, land bank or small business transactions; $\$ 2 \mathrm{r}_{7}$ forbids acceptance of consideration for a compromise of farm indebtedness under the feedral farm loan program. Sections 2ro-2I7 were not part of Pub. $L$. $87-849$.

${ }_{20}$ Included are employees or officers of the District of Columbia government.

${ }^{27}$ Persons serving as part time representatives of members of Congress in the member's home district or state are classified as special government employees regardless of the duration of their appointment, and a Reserve Officer of the Armed Forces or an Officer of the National Guard either of whom is serving involuntarily is classified as a special government employee regardless of the duration of such duty. Enlisted personnel of the armed services are neither regular nor special government employees.

${ }^{28}$ This interpretation is based on the President's Memorandum on Preventing Conflicts of Interest on the Part of Special Government Employees, May 2, 1963,28 Fed. Reg. 4539 (I963), and leaves open the possibility of avoiding certain strictures of the new law by artificially making short term appointments. There is little doubt that any substantial abuse of the "special employee" classification would be questioned by the Comptroller General. If an individual is appointed on the same date to serve more than one agency, the duration estimates are added together to determine whether or not he qualifies as a special employce. Should the additional appointments not occur on the same date, then the employee's status is determined by adding the number of days already worked since the first appointment to the estimate of days to be worked for each agency at the time of the later appointment. If this total exceeds 130 days out of the $3^{65}$ day period beginning with the date of the first appointment, the employee loses his "special" status. The duration of a special employee's appointment extends from the day the appointment takes effect until the day it ends, regardless of the actual number of days worked during that period.

${ }^{30} \mathrm{Id}$. at 4545 . Even though the "representative" may receive a travel allowance or "per diem" in lieu of travel expenses, he does not necessarily lose his exempt status thereby. Other factors that may be relevant in determining whether a particular person is a "representative" rather than a special Government employee are: membership on a committee organized specifically for the purpose of presenting the viewpoints of non-governmental groups or organizations; the fact that he is appointed to an agency by a non-governmental organization, and not in a position to act as a spokesman for the government. 
stantial interest. The prohibition covers officers and employees in all branches, departments, and agencies of the federal government, including members of Congress, and makes the person offering the special compensation subject to its penalties along with the recipient. ${ }^{30}$ Although the section enumerates appearances before courtsmartial as a proscribed transaction, it pointedly does not mention other judicial actions and must, therefore, be construed not to cover proceedings before a regular court. It is not clear from its wording whether the prohibition of section 203 applies to any services rendered in connection with proceedings before any department, agency, and so on, or whether it applies only to services rendered before any department in connection with any proceedings. The first interpretation is obviously the more inclusive, but the second appears to represent the currently prevailing view. ${ }^{31}$ The application of section 203 is restricted in three significant areas: (a) It applies to a "special Government employee" only in a matter involving a specific party in which he has participated personally and substantially or in a transaction pending before a department or agency in which he has served more than sixty out of the previous 365 consecutive days; $;^{32}$ (b) it does not preclude an officer or employee from acting as agent or attorney on behalf of his immediate family or any estate or person he represents as a fiduciary except with respect to those matters in which he has participated personally and substantially as part of his official duties; ${ }^{33}$ (c) the third restriction in the application of section 203 applies only to special government employees and seems well adapted to protect the eligibility of a prospective government contractor or grantee whose employee is called in as a consultant on a procurement matter of possible interest to his private employer. If the cognizant government department or agency head specifically certifies in writing that the national interest so requires and causes this certification to be published in the Federal Register, a special Government employee can act as attorney or agent for another person in the performance of work under a federal government grant or contract. There are no other qualifications on this exemption and its application obviously extends to matters in which the special employee may have participated directly and personally. ${ }^{34}$ Section 203 has a direct impact on procurement activities and it is clear

\footnotetext{
${ }^{30}$ The effect of the prohibition is government wide. It applies to a particular employce with respect to transactions before any other government agency and forbids compensation for pre-employment services and before or after the fact payment for services rendered during the period of government employment. Section 201 and this subsection of $\$ 203$ also carry as a penalty for their violation permanent disqualification from responsible federal office, in addition to fine and imprisonment.

${ }^{31}$ For further discussion of this point, see Perkins, The New Federal Confict-of-Interest Law, 76 HARV. L. Rev. III3, II45 ( 1963 ).

${ }^{32}$ The latter restriction applies throughout his department or agency (but is not government-wide) whether or not the special employee participated in the transaction or even was aware of it. Note that the 6o-day rule is retrospective and includes only actual days worked, rather than prospective, as is the I30-day rule. Time worked at another agency does not contribute toward the 6o-day period.

${ }^{33}$ In order to act in this capacity, the government employee must obtain the approval of the official who appointed him.

${ }^{34}$ It is not clear why the words "attorney or agent" were used when the exemption appears to cover all of the activities to which $\$ 203$ applies.
} 
that any special services by a government official to a contractor or prospective contractor for which compensation is received are within its prohibition.

Section 204 plugs one of the obvious loopholes left open by section 203. It simply prohibits members of Congress and resident commissioners from practicing before the Court of Claims. The prohibition includes elected congressmen or commissioners even though they may not yet have taken office. In addition to fine and imprisonment for conviction of violating this section, lifetime disqualification from holding government office may be imposed.

Section 205 is very similar to section 203 with respect to its application and exceptions and like section 203 covers acts of government officials as representatives of outsiders. There are, however, some significant distinctions between the two provisions. Section 205 covers representational activity as agent or attorney in the prosecution of claims against the government or in appearances before any court, department, agency or commission in connection with any proceeding, contract, or other transaction in which the government is a party or has a direct or substantial interest. Also expressly barred is the receipt of any gratuity, share of or interest in any claim as consideration for assistance in its prosecution. The prohibition applies to all government officials and employees in acts representing private persons (outside the government) as does section 203 , but, unlike that section, does not apply to members of Congress. Also of significance is the fact that section 205 covers court actions, while section 203 does not. This anomaly preserves the loophole carved by section 203 permitting congressmen to handle court cases ${ }^{35}$ in which the federal government is a party or has a substantial interest. The most substantial difference between sections 203 and 205 is that compensation must have been solicited or received for the services rendered in order to bring such activity within the prohibition of section 203, whereas section 205 bars the described representational activities whether compensation is solicited or received for them or not. Although these two sections employ different language to describe the prohibited activities they cover, ${ }^{36}$ the Department of Justice interpretative memorandum ${ }^{37}$ discussing the new legislation regards the sections as applying to similar kinds of acts with the exception of court actions. Section 205 also has exactly the same restrictions in its application to

${ }^{35}$ Except, of course, before the Court of Claims as prohibited by $\$ 204$.

${ }^{30}$ Section 203 refers to "official duties or services in relation to any proceeding, application, request for a ruling or other determination, contract, claim, controversy, charge, accusation, arrest, or other particular matter in which the United States is a party or has a direct or substantial interest, before any department, agency, court martial, officer, or any civil, military or naval commission." Section 205 specifies "acts as agent or attorney for anyone before any department, agency, cottrt, court martial, officer, or any civil, military or naval commission in connection with any proceeding, application, request for a ruling or other determination, contract, claim, controversy, charge, accusation, arrest, or other particular matter in which the United States is a party or has a substantial interest." While it seems apparent that the "representational activity" covered by $\$ 205$ is not limited to personal appearances and can include other modes of communication with federal officials such as the signing of bids or contracts, the scope of this section as to prohibited activities does not seem quite as broad as that of $\S 203$ with its sweeping reference to "services."

${ }^{37}$ Department of Justice Memorandum Regarding Conflict of Interest Provisions of Public Law No. 87-849, Jan. 28 , I963, 28 Fed. Reg. 985,987 ( Ig63). $^{2}$. 
special government employees and family or fiduciary representation as has section 203. One additional exemption from the application of section 205 is added. No officer or employee is prevented from acting without compensation as agent or attorney for any person who is the subject of disciplinary, loyalty, or other personnel proceedings unless to do so would directly conflict with that official's duties. ${ }^{38}$ A phrase in section 207 (c) makes section 205 applicable to partners of officials and executives in the executive branch but imposes a lesser penalty on them. ${ }^{30}$

Section 206 is very brief and states that sections 203 and 205 do not apply to retired officers of the uniformed services of the United States while not on active duty, unless they otherwise qualify as government officers or employees. This section also excepts from the application of sections 203 and 205 government officials and employees and other persons specifically exempted by other statutes. ${ }^{40}$

Section 207 deals with postemployment disqualification of federal officials and employees of the executive branch or independent agencies ${ }^{41}$ in matters connected with their former duties or official responsibilities. Part (a) of the section forbids any acts as agent or attorney by a former government official or employee before a court, department, agency or commission in connection with particular matters involving specific parties in which the government is a party or has a direct and substantial interest and in which the former employee or official participated personally or substantially. This prohibition refers primarily to representational activity and binds special government employees as well as regular ones. The ban imposed by section 207 (a) is permanent. Since the subsection applies to specific transactions, it ordinarily would not include acts associated with rule-making or formulation of general policy.

Part (b) of section 207 applies to the same class of employees and officials as

${ }^{83}$ Does this exception apply to "special government employees" even though they are not specifically designated? The Department of Justice interpretative memorandum states that the words "government officer or employee" include "special government employees" even though come sections of the statute use the wording "officer or employee, including special government employee." Id. at 987 n.5. It is also probable that this exemption applies to $\$ 203$.

${ }^{30}$ There is every reason to believe that the application to partners of government officials and employees in the executive branch operates on section 203 as well. The penalties applied to partners for violation of the sections applicable to them are a fine not to exceed $\$ 5,000$ or imprisonment for not over one year or both.

${ }^{40}$ The provision concerning statutory exemptions appears to be primarily prospective in its outlook. A number of statutes currently in effect carry specific exemptions from some or all of the laws rclating to conflicts. Included among them are: the Defense Production Act of 1950, 64 Stat. 819 (x950), as amended, 50 U.S.C. App. $\$ 2160$ (I958); the Renegotiation Act of 195I, 65 Stat. 22 (195I), as amended, 50 U.S.C. $\$ 1223$ (1958); the Mutual Security Act, 75 Stat. 451 (I96I), as amended, 22 U.S.C. $\$ 2386$

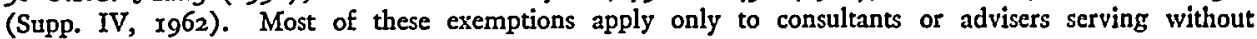
compensation.

Section 2 of Pub. L. No. 87-849, 18 U.S.C. $\$ 281$ (Supp. IV, I962) expressly extended previous statutory exemptions from the conflict of interest laws (18 U.S.C. $\$ \$ 281,282,283,284,434$ (1914)) to the new act as such exemptions applied to officials and employees in the legislative and judicial branches. Section 2, however, repealed all prior statutory exemptions as they applied to officers and employees in the executive branch or in independent agencies and the government of the District of Columbia.

${ }^{\star 1}$ Including employees of the District of Columbia. 
does part (a) and sets up a one year post-employment prohibition with respect to those matters that were the "official responsibility" of the employee or official at any time during the last year of his government employment. ${ }^{42}$ The prohibition applies only to personal appearances as agent or attorney but would probably cover a person signing a brief submitted in connection with an action before a board of contract appeals. The reach of section $207(\mathrm{~b})$ is specific enough so that if an employer or official transferred from the Department of the Air Force to the National Aeronautics and Space Administration (NASA), worked at NASA for eight months and then resigned to accept employment with a private electronics company, the post-employment ban with respect to his official responsibilities as an employee of the Air Force would end four months after accepting the private employment, provided that there was no overlap of those responsibilities in his work with NASA. One caveat, however, is worthy of mention. Section 207(a) and (b) applies to both regular and special government officers and employees whereas sections 203 and 205 exempt special government employees from most of their application. It could happen, therefore, that a special government employee to whom the prohibitions of the statute did not apply during the period of his government employment could come within the one year post-employment ban of section 207 (b) with respect to matters that were within the scope of his official responsibilities. ${ }^{43}$ Government employees (regular or special) having scientific or technological qualifications can be exempted from the application of section 207 with respect to particular matters in the scientific or technological field if the head of the department or agency concerned certifies that such exemption is in the national interest and publishes this certification in the Federal Register.

Since the activities proscribed by section 207 (a) and (b) are primarily representational in character, a former government official would not be precluded from aiding or assisting his private employer in connection with work for which he had official responsibility while with the government. He would, however, violate the terms of the section by negotiating for his employer a change order of a contract the statement of work for which he had prepared while he was a government official.

Section 207 (c) imposes some special restrictions on those who stand in a partner-

"The term "official responsibility" is defined in section 202 as "the direct administrative or operating authority, whether intermediate or final, and either exercisable alone or with others, and either personally or through subordinates, to approve, disapprove, or otherwise direct government action." It is clear that the term "official responsibility" is broader in applying to the official acts of the government official than is the expression "matters in which he participated personally and substantially" used in section 207 (a). Official responsibility appears to refer to those matters which were before his department or agency during the final year of his employment and which he could affect either directly or indirectly. The concept probably embraces "staff" as well as "line" responsibilities. See Perkins, supra note $3 \mathrm{r}$, at $\mathrm{I} 228$.

${ }^{48}$ As pointed out in the Department of Justice Interpretive Memorandum, supra note 37 , at 987 n.7, the official responsibilities of special government employee are not likely to be very extensive. Note that the prohibitions of subsections 207 (a) and (b) apply to a former employes $f$ the executive branch even though he may not have left the government entirely but merely transfe-ied to a position in the legislative or judicial branches, supra note 37 , at 987 n.6. 
ship relation to general or special government officials and employees in the executive branch or in independent agencies. Such partners are prohibited from acting as attorneys or agents for anyone but the federal government in any judicial or other proceeding (including contract matters) in which the government has a direct interest and in which the government partner participated directly and substantially or had official responsibility. Here, again, the ban covers representational activity and applies only during the actual period during which the government partner is employed. The most important problem with respect to partners is whether the nongovernment partner is subject to criminal penalty because of the forbidden acts of his partner who is a government employee or official and who violates one of the provisions of the new law, and vice-versa. It is probable that no imputation of guilt to a partner occurs because, if it did, the exculpatory clause that concludes subsection (c) would be meaningless. ${ }^{44}$ The prohibition with respect to partners does not apply unless one of them is currently in the government service and it is thus strange that it was placed in section 207. The substantive application of the restraints on nongovernmental partners of government officials and employees is solely with respect to the representational activities covered by sections 203 and 205 and does not apply to post-employment activity. The application of section 207 is specific and receipt of compensation is not a condition for its violation. It has particular import to the government procurement official who decides to resign from the federal service and try his fortunes in industry.

Section 208 is directed at personal financial interests of government officials and employees and applies only to those in the executive branch or in independent agencies. ${ }^{45}$ It prohibits any such person from representing the government in a judicial or other governmental proceeding with respect to a matter in which he has a financial interest. Section 208 applies to acts of officials as representatives of the government in contrast to sections 203 and 205 which apply to acts of officials as representatives of persons outside the government. The section is all inclusive as to types of transactions covered and its prohibition extends to financial interests in all kinds of private organizations ${ }^{46}$ in which the government official may be a partner,

\footnotetext{
"See Perkins, supra note 3I, at Ir60-6r. The exculpatory clause of subsection 207 (c) provides that the nongovernmental partner shall be subject to the provisions of sections 203, 205, and 207 only as expressly provided in section 207 (c). This wording negatives the imputation doctrine with respect to the nongovernment partner, and its reciprocal operation in favor of the government partncr appears also to be a logical conclusion.

${ }^{45}$ Also specifically covered by this section are special government employees and employees of the District of Columbia.

${ }^{4}$ Section 208 covers participation through "decision, approval, disapproval, recommendation, the rendering of advice, investigation or otherwise in a judicial or other proceeding, application, request for a ruling or other determination, contract, claim, controversy, charge, accusation, arrest, or other particular matter, in which, to his knowledge he, his spouse, minor child, partner, organization in which he is serving as officer, trustee, director, partner or employee ...." The prohibition applies to "particular matters" as distinguished from policy formulation or general rule making. The organizations covered would include non-profit as well as commercial ones. As Perkins points out, the non-partnership interests of the government employee's partner or the non-organizational personal interests of his other business associates would presumably not come within the prohibition of $\$ 208$. Perkins, stupra note 3T, at II32.
} 
officer, director, trustee, or employee or to any person or organization with which he may be negotiating or have an arrangement for future employment. Any financial interest in the particular transaction on the part of the spouse, minor child, partner, or organization with which he is affliated that is known to the government official violates the prohibition of section 208 .

There are two important exemptions from the application of section 208. It does not apply to a government official or employee who makes full disclosure of his financial interest to the government official who appointed him and receives a written determination from that official that improper conflict of interest is not involved. Nor does it apply to classes of employees that have been exempted by general regulation published in the Federal Register on the basis that their financial interest is not substantial enough to impair their integrity. This provision provides an admirable mechanism for clarification of troublesome financial interest questions through the issuance of general regulations.

Section 209 places a limitation on outside compensation of government officials. It too applies only to regular employees and officers of the executive branch and independent agencies ${ }^{47}$ and prohibits them from receiving any salary or other compensation for performance of their official duties except from a governmental source, be it federal, state or local. ${ }^{48}$ The penalties of section 209 apply equally to the payor and the payee of such emoluments. There are, however, some important exceptions to the application of this section. It does not prevent any of the employees to whom it applies from accepting income from a pension, retirement, insurance or other benefit plan provided by a former employer. This provision is a frank recognition of the significance of vested security plans and should make it much easier for government agencies to recruit qualified personnel. It permits the government official to be rewarded for past services to a private employer without compromising his integrity and usefulness as a public servant. ${ }^{49}$ Nor does section 209 bar outside compensation to any government official or employee, be he regular or special, who is serving without compensation. ${ }^{\text {50 }}$

The final substantive section of Public Law $87-849$ is section 218, a catch-all section designed to bestow on the government a special remedy where there has been any violation of the earlier sections of the chapter. ${ }^{51}$ Whereas the first section.

${ }^{47}$ Employees and officers of the District of Columbia government also come within the scope of this

${ }^{\Delta 8}$ Section 209 appears to proscribe anything that can be called compensation. It seems clear that the employer of a business executive would be precluded from making up the difference between the govcrnment salary of the executive while in the federal service and his former salary in private industry. The Comptroller General has also ruled that a government official cannot accept expenses of official travel from outside sources, 36 Decs. CoMp. Gen. I55 (1956). This section does not, however, place any restriction on income received from legitimate outside employment.

4 Section 209 imposes no requirement that pension and retirement plans qualify under the provisions of the Internal Revenue Code, nor does it set up any other criteria for eligibility.

${ }^{\circ 0}$ Section 209 does not apply to payment or acceptance of payments under the Government Employees Training Act, 72 Stat. 237 (1958), 5 U.S.C. $\$ 52301-2319$ (Supp. IV, 1962).

${ }^{61}$ I 8 U.S.C. $\$ \$ 201-217$ (Supp. I962). 
seventeen sections pertain to acts by individuals in their official capacity, section 218 refers uniquely to their acts. It specifies that any act ${ }^{52}$ performed in connection with a violation of any of the sections in chapter eleven for which there has been a conviction may be treated as void and without effect by the department or agency head concerned. Furthermore, it permits the government to recover any money expended or thing transferred or the value thereof. Since these remedies are specified to be in addition to any others provided by law, the rule laid down in United States $v$. Mississippi Valley Generating $\mathrm{Co}^{53}$ is left standing and it appears that the government may be able to cancel a contract made in violation of Public Law 87-849 even though there has been no actual conviction.

There is no doubt that the new legislation represents a vast step forward in the control of conflict of interest in the federal government. It places a whole new arsenal of legal weapons at the disposal of enforcement authorities who must deal with this problem. Even so, some critical comment on the new law is appropriate. The new legislation is all penal in nature and thus wields a big stick where, in some types of cases, a small one would do the job better. It is a well-known fact that the penal statutes that made up the old law relating to conflicts were very seldom invoked. Although the new statute will undoubtedly have a strong deterrent effect, it may be too severe for use in many situations. There is not a single section in the new law that simply provides for removal of the offending government employee, often the best solution for many problems. Nor are there any useful statutory guidelines in many related areas such as improper use or disclosure of confidential government information, ${ }^{54}$ outside employment and ex parte communications.

The new act is unduly complex and will be difficult to interpret and administer. Much of this needless complexity resulted from the efforts to exempt members of Congress from certain provisions of the law. The new legislation also falls somewhat short of a goal that could have been achieved through a blanket prohibition of gifts to government officials and employees. The test of an unlawful gratuity should be: did it come from someone with whom the government person has dealt, is now dealing or might deal in his official capacity? If so, it should be illegal per se. The present test of whether a gratuity has influenced the government offcial places an unnecessary and cumbersome burden of proof on him who would assert wrongdoing.

With respect to conflict of interest problems involving retired regular officers of the armed and other uniformed services, the new legislation merely compounded already existing confusion. This problem will be discussed in detail later in this article.

${ }^{52}$ Specifically mentioned are contracts, loans, grants, subsidies, licenses, rights, permits, franchises, uses, authority, privileges, benefits, certificates, rulings, decisions, or rate schedules awarded, granted, paid, furnished or published, or the performance of any services or transfers or deliveries of anything to, by or for any agency of the United States or officer or employee of the United States or person acting in behalf thereof.

${ }^{53} 364$ U.S. 520 (196r).

"Here the term "confidential government information" is not intended to refer to information affecting national security, the use and disclosure of which is controlled by other statutes and regulations. 


\section{Other Legislation Affecting Conflicts}

Although Public Law $87-849$ represents the bulk of general legislation pertaining to conflict of interest, there are several other older statutes that have a direct or indirect bearing on conflicts and apply particularly to procurement activities and in some instances to specific agencies or persons.

A section in the Armed Services Procurement Act of $1947^{55}$ and its counterpart in the Federal Property and Administrative Services Act of $1949^{56}$ are directed at the payment of contingent fees, an arrangement that is the lifeblood of influence peddling. Every recipient of a negotiated government contract is required to execute a warranty that no contingent fee has been paid to obtain the contract except to a bona fide employee or a regular selling agency. ${ }^{57}$ These statutes are not penal but do permit the government to annul the contract without liability and recover any contingent fee that was paid if the warranty is breached. ${ }^{58}$ Since the criteria with respect to legitimate payment of contingent fees have become well defined, there has not been serious difficulty with the use of this warranty clause in recent years. The important thing is that the would-be contractor avoid any contingent fee arrangement with a representative or selling agent that has the appearance of a specific attempt to obtain a particular contract.

The Subcontractor Kickback $A c t^{59}$ is unique in that it does not apply to government officials at all, but it is significant in the procurement areas because it prohibits certain conflict of interest abuses between government contractors and subcontractors that could be detrimental to the government. Specifically, the act bans the payment of any consideration by or on behalf of a subcontractor in connection with the furnishing of goods or services to a prime contractor or any representative thereof who holds a negotiated contract with the federal government. ${ }^{60}$ The government is empowered to recover any monies paid out by prime contractors in violation of the act and persons participating directly or indirectly in the paying or receiving of

ธש 10 U.S.C. $\$ 2306$ (1958).

${ }^{80} 63$ Stat. 395 (I949), 4I U.S.C. $\$ 254$ (1958).

${ }^{67}$ Both the Armed Service Procurement Regulation (ASPR) ( $\$$ I-505), 32 C.F.R. $\$$ I.505 (196I) and the Federal Procurement Regulation ( $\$$ I-Y.505), 4I C.F.R. $\$$ I.x-505 (I963) contain detailed criteria for determining whether the exceptions to the covenant against contingent fees apply in a given case. A special form of warranty is used so that if the contractor states that a contingent fee was paid to other than a full time employee, he is obliged to make a full disclosure of the circumstances in order that the procuring agency can ascertain whether the statutory policy with respect to such payments has been violated. The warranty on contingent fees must usually be submitted with the bid or proposal that precedes a contractual undertaking.

"The wording "without liability" seems to mean that the government would be obligated to pay for any benefits received prior to cancellation of the contract, less the amount of the contingent fee paid. The contractor may also be subjected to administrative blacklist for violating the warranty.

${ }^{60} 60$ Stat. 37 (1946), as amended, 74 Stat. 740 (I960), 4 I U.S.C. § 5I (Supp. IV, I962).

${ }^{\circ 0}$ The prohibition also extends to payments between lower tier subcontractors on the theory that the cost of such payments will ultimately be reflected in the cost or price paid by the prime for subcontractual work. The contracting officer is empowered to withhold payments to the prime contractor if subcontractor kickbacks are reported to him and the General Accounting Office has authority to investigate any suspected violations of this statute. 
such sums are subject to criminal penalties. ${ }^{61}$ The effect of this anti-kickback statute is to impose essentially the same standard of conduct on government subcontractors that the anti-bribery statutes impose on prime contractors and others in their dealings with government officials. The prohibitions and penalties of the act do not apply unless there is a "chain of contractual relationships" down to the violator.

Since I95I, there has existed a statutory requirement that all contracts involving the expenditure of funds appropriated for the use of the Department of Defense contain a clause prohibiting gratuities. ${ }^{62}$ The gratuities clause gives the government the right to terminate a contract containing it if it is found that gratuities (gifts, entertainment, and so forth) were offered by the contractor or his representative to any officer or employee of the government "with a view toward" 33 securing a contract or favorable treatment in the administration of such contract. If a violation is found, the clause also gives the government the right to pursue its other remedies for breach of contract and to assess against the contractor damages of not less than three nor more than ten times the cost of the gratuity. The secretary of the military department cognizant of the contract is required to have a hearing conducted in order to determine whether a contractor charged under the clause is guilty, for which notice is given and evidence taken by testimony and deposition. ${ }^{64}$ The final decision in the matter is rendered by the Secretary of the department and the contractor has the right of appeal to the courts. ${ }^{65}$ The Gratuities Act covers many of the things prohibited by sections 201, 203, and 205 of the new conflicts legislation, but its sanctions are directed solely against the contractor and the contract concerned. It is not a penal statute and does not apply to individuals either in or outside of the government. The prohibitions are directed uniquely at procurement operations and apply only to contracts financed by Department of Defense appropriations.

\section{Laws Governing Congressional Conflicts}

The remaining special conflict of interest laws apply solely to members of Congress, delegates to Congress and resident commissioners. ${ }^{68}$ One statute ${ }^{67}$ subjects to

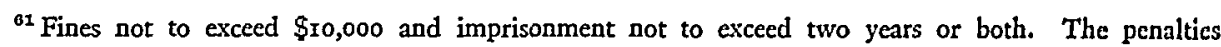
of the act apply to both the offeror and the recipient.

${ }^{62}$ After appearing in several Defense appropriation acts, permanent legislation codifying this requircment was enacted in 1954,68 Stat. 353 (1954), 5 U.S.C. \& I74d (r958).

${ }^{\circ}$ The use of these words quoted from the statute is interesting. This phrase avoids the use of the word intent and thus proof of specific intent would not seem to be required. The government would, however, have to prove some connection between the gratuity and the receipt of a contract or favorable treatment thereunder. As in the case of $\$ \S 201,203$ and 205 of Pub. L. No. 87-849 some cause and cffect relation must be shown. The Gratuities Act could, and should, but does not, outlaw a pure gift.

${ }^{64}$ Appendix D of the Armed Services Procurement Regulation, 32 C.F.R. $\$ 21$ ( 1963 ), sets out the procedures to be observed in the conduct of this hearing.

${ }^{85}$ It should be noted that the giving of gratuities can subject the donor or offeror to other penal sanctions such as prosecution for bribery under $\$ 20$ r of Pub. L. $87-849$, fraud against the government, I 8 U.S.C. $\$ 37$ I (1958) or conspiracy to defraud, I8 U.S.C. $\$$ Ioor (I958). The Armed Services Procurement Regulation $\$ \mathrm{I}-604 . \mathrm{I}, 32$ C.F.R. $\$ \mathrm{I} .604-\mathrm{I}$ ( $\mathrm{I} 96 \mathrm{I}$ ) provides that an administrative debarment for up to three years may be imposed on a contractor violating the gratuities clause thus creating an ineligibility for the award of Defense Department contracts for such period.

${ }^{\circ 0}$ There are currently no delegates to Congress and only one resident commissioner, who is in Puerto Rico.

${ }^{\text {a7 }}$ I 8 U.S.C. $\$ \$ 43 \mathrm{I}-432$ (I958). A civil provision, 50 Stat. 838 (I937), $4 \mathrm{I}$ U.S.C. $\$ 22$ (I958), 
a fine of $\$ 3,000$ any congressman or commissioner who enters into or receives benefit from any contract with a federal department or agency. The penalty also applies to the government official awarding the contract. Furthermore, any contract made in violation of this ban is void and the consideration paid by the government under such a contract is subject to recovery in a suit at law. There are, however, a number of exceptions to this law, usually referred to as "Officials Not to Benefit," which considerably weaken its impact. Although the prohibition applies to a firm of which the congressman is a partner, it does not cover a contract made by the corporation for its benefit ${ }^{68}$ even though a congressman may own as much as a thirty per cent interest and function as its president. ${ }^{69}$ Nor does it prevent a congressman from acting as surety on a bond for a government contractor. ${ }^{70}$

Despite the numerous prohibitive statutes that apply to them, members of Congress present some acute problems with respect to conflict of interest. Existing laws do not begin to get at the heart of the matter. Only two parts of the general conflicts statute (Public Law 87-849) apply to congressmen. They are section 201 covering bribery and section 203 proscribing special assistance to individuals outside of the government. But neither of these sections is violated unless an attempted or actual exchange of something of value is involved and some connection between this consideration and the improper act can be proved. The older sections 431 and 432 merely forbid members of Congress from entering into contracts with the government and there are many situations in which this prohibition does not apply. Possibly one of the best deterrents that relate to congressmen is a statute making it unlawful for individuals and firms to make any political contributions during the period of negotiation or performance of a contract financed by appropriated funds. ${ }^{71}$ This prohibition has serious limitations since it applies only to the period of actual contract activity or negotiation and its sanctions apply only to the offerer or solicitor of the contribution.

Although many obvious abuses are outlawed by existing laws, the real difficulty arises when congressmen attempt to influence official government action for the benefit of their constituents or for personal business and financial reasons. Any conflict of interest statute designed to eliminate this abuse must steer a difficult course between controlling, at one extreme, the great power of the legislators because of their control over appropriations on which everything the government

requires that the "Officials Not to Benefit" condition be expressed in all government contracts covered by the penal statute.

${ }^{88}$ I 8 U.S.C. $\$ 433$ (I958). The remaining exemptions apply to transactions with specific government agencies or under particular statutes such as the Agricultural Adjustment Act and the Home Owners' Loan Act. Exemptions to the application of the prohibition must be made a matter of public record.

${ }^{80} 39$ Ops. ATtT. Gen. I65 (1938).

${ }^{70} \mathrm{x} 8$ id. $286(1885)$.

${ }^{71}$ I8 U.S.C. $\$ 6$ I I (x958). The prohibition covers the solicitation as well as the making or promise of political contributions by direct or indirect means. The statute is penal and carries a fine of not over $\$ 5,000$ and imprisonment not to exceed five years or both for its violation. The law covers only prime contractors with the government and applies either to business entities or to the individuals representing them. 
does depends, and, at the other end of the spectrum, preserving the time-honored "representative role" through which congressmen act as champions for constituents in their struggles with government bureaucracy.

It is one thing when a senator who has no committee or other legislative responsibility with respect to a particular government agency writes a follow-up letter on behalf of a constituent inquiring about the status of some administrative action pending before that agency. It is quite another when the chairman of a powerful Senate Committee writes a letter to the agency for which he has legislative responsibility advocating a specific course of action favoring a corporation of which he may be a substantial stockholder in connection with a case pending before the agency. Federal procurement is an area particularly sensitive to congressional influence even where conflict of purely economic interest may be a relatively minor factor. When the award of a large procurement contract is involved, political pressures sometimes become very great even though the member of Congress may not have a direct financial interest. The recent TFX controversy is a case in point. It is very difficult for the cognizant agency to carry out established procurement policy-laid down by Congress itself in most instances-in the face of interference and pressure from members of Congress. In the case of major procurement actions, as with other important government moves, perhaps the ultimate question to be answered is: Where should the final decision be made, in the executive or in the legislative branch of the government? One strong argument against congressional intervention is that improved administrative procedures and safeguards now established in government departments and agencies have substantially decreased the likelihood of injustice in the decision-making process. ${ }^{\mathbf{7 2}}$ This is particularly true of procurement actions.

Congressmen appear very willing to apply a strict code of ethics to everyone but themselves. This double standard currently being employed by Congress with respect to conflicts of interest is receiving ever greater public attention. ${ }^{\mathbf{7 3}}$ It is suggested that the worst of the problem could be eliminated by a statute making the following three provisions:

a. Close the loophole in Public Law 87-849 that now permits congressmen to handle court cases in which the government is a party or has a substantial interest.

b. Prohibit congressmen from representing or assisting in proceedings of any kind involving the government (whether in executive, judicial, or legislative branches) any private individuals or business entities in whch such congressman has a substantial economic interest. This prohibition to apply whether or not compensation is received. ${ }^{\mathbf{7}}$

${ }^{72}$ The widespread use of quasi-judicial tribunals and high-level boards that review the decisions of agency officials is one obvious example of improved administrative procedure. The system is not perfect yet, but great progress has been made.

${ }^{73}$ See Bogdikian \& Oberdorfer, Conflict of Interest, Can Congress Crack Down on Its Own Members?, Saturday Evening Post, Nov. I7, rg62, p. 21.

7 Logically, this disability should also apply to voting in Congress. It is not considered desirable to include such a prohibition in a public statute. The matter could easily be handled as part of the individual rules of the Senate and House of Representatives. Disclosure of the financial and business interests of members would make it fairly easy to establish criteria for voting disqualification. 
c. Require all congressmen to make their financial and business interests a matter of public record with criminal penalties for falsification.

Such a measure would make enforcement of existing laws pertaining to congressional conflicts much easier and eliminate most of the currently flagrant abuses. Equally important, the provision would not limit or impair the "representative" function of congressmen with respect to their constituents except in cases where the legislator has a substantial personal economic interest. Such a restriction scarcely needs any justification. Congressmen might find the imposition of these measures more palatable if they were given more adequate coverage of expenses arising from the necessity of maintaining large office staffs and dual residences.

The practical fact still remains that if a meaningful law binding congressmen to the same conflict of interest standard that has been imposed on the rest of the government is to come into being, Congress itself will have to enact it. In the face of existing attitudes, the probability that such legislation will soon be passed is slim. Some positive action in this area will have to be taken shortly if public confidence in the integrity of Congress is to be maintained.

\section{Regulations}

Any discussion of government department and agency regulations relating to conflict of interest can well take as its point of departure the Code of Ethics for all government employees passed as concurrent resolution $\mathrm{I} 75$ by the Eighty-fifth Congress. This Code contains ten provisions, three of which pertain directly to conflict of interest. ${ }^{75}$ It cites as improper conduct any discrimination in the performance of public duties, receipt of compensation which might appear to have influenced official acts, participation in business with the government in a manner inconsistent with the conscientious performance of official duties, and use of confidential or inside government information as a means of making personal profit.

${ }^{75}$ Code of Ethics for Government Service. Any person in government service should:

x. Put loyalty to the highest moral principles and to country above loyalty to persons, party, or government department.

2. Uphold the Constitution, laws, and legal regulations of the United States and of all governments therein and never be a party to their evasion.

3. Give a full day's labor for a full day's pay; giving to the performance of his duties his earnest effort and best thought.

4. Seek to find and employ more efficient and economical ways of getting tasks accomplished.

5. Never discriminate unfairly by the dispensing of special favors or privileges to anyone, whether for remuneration or not; and never accept for himself or his family, favors or benefits under circumstances which might be construed by reasonable persons as influencing the performance of his governmental duties.

6. Make no private promises of any kind binding upon the duties of office, since a government employee has no private word which can be binding on public duty.

7. Engage in no business with the government either directly or indirectly, which is inconsistent with the conscientious performance of his governmental duties.

8. Never use any information coming to him confidentially in the performance of governmental duties as a means for making private profit.

9. Expose corruption wherever discovered.

ro. Uphold these principles, ever conscious that public office is a public trust. 
The coming into effect of Public Law $87-849^{76}$ with its extensive changes in the law relating to conflict of interest resulted in the issuance of many new regulations by the various government departments and agencies. It is not a uniform characteristic of these regulations to incorporate specific penalties for their violation. They are, however, binding on the conduct of the officers and employees to whom they apply, and in numerous places reference is made to the fact that breach of the regulations may be the basis for discharge or disciplinary action. Some of the regulations apply only to personnel within the agency, others affect outsiders who deal with the agency.

Many of the new regulations have in common an interpretation and commentary on the new conflicts statute. From there, they deal with various matters that are the special interest of the particular agency. Most of the regulations do, however, touch on such things as gratuities, gifts to superiors, bribery and graft, outside work and financial interests.

The President's Memorandum on Preventing Conflicts of Interest on the Part of Special Government Employees ${ }^{77}$ contains a special section on ethical standards of conduct, and part of that section is devoted primarily to a discussion of the proper use of inside information, a matter not dealt with in the new conflict of interest statute. The memorandum specifically enjoins special government employees from using inside or confidential information to which they have access because of their official duties for personal profit. Neither the special employee nor members of his family or business associates are permitted to use such information for speculative gain. ${ }^{78}$ A previous executive order ${ }^{79}$ applying only to presidential appointees lays down prohibitions against non-compatible outside employment, gratuities, use of public office for private gain, giving preferential treatment to anyone, and outside compensation of any kind connected with official duties. ${ }^{80}$

Because of its dominant role in procurement, the Department of Defense regulations regarding conflict of interest are highly developed and of particular interest. Defense Directive $5500.7^{81}$ sets out the standards of conduct required of personnel in all of the subdivisions and agencies of the Department of Defense. ${ }^{8 D}$ The Directive warns personnel against using their official positions to induce, or give the appearance of inducing, another person to impart any economic benefit to them, their families or business associates. Specifically mentioned in this connection is the use of inside information.

${ }^{76}$ I8 U.S.C.A. $\$ \$ 201-218$ (Supp. 1963).

${ }^{77} 28$ Fed. Reg. 4539, 4544 (I963).

${ }^{28}$ This prohibition extends also to regular officers and employees of the government. This memorandum covers only special employees as defined in Pub. L. No. 87-849.

${ }^{70}$ Exec. Order No. I0939, 26 Fed. Reg. 395 I (196r).

${ }^{80}$ Excepted from the prohibition is outside reimbursement for reasonable travel and living expenses for which no government payment is made. This would permit the official to receive rcimbursement connected with personal appearances at technical, cultural or political meetings and the like.

${ }^{81} 28$ Fed. Reg. 5666 ( 1963 ).

${ }^{82}$ Including all officials, civilians, officers and enlisted men of the Army, Navy, Air Force, and Marine Corps. 
After a brief recital of the criminal penalties attaching to conviction for bribery and graft, the Directive makes specific reference to the problem of gratuities. It forbids the receipt by Department personnel or their families of any favor, gratuity or entertainment that might affect, or might reasonably be interpreted as affecting, complete objectivity and fairness in the performance of their official duties. Gratuities from persons or organizations engaged in or seeking business dealings with the Department are specified as within the proscribed category. It is clear that the definition of a gratuity in this regulation is broader than that in Public Law 87-849 or in the special statute ${ }^{83}$ discussed earlier. The definition here comes close to a ban on pure gifts and conceivably could be strictly interpreted as exactly that. Its application in practice has been somewhat more moderate. Although substantial gifts, extravagant entertainment such as "girlie parties," expense paid vacations and the like clearly violate this regulatory concept of a gratuity, the time honored "contractor furnished lunch" and other amenities reasonably related to the conduct of business probably do not.

Defense Directive 5500.7 places a flat prohibition on the making of gifts or contributions to superiors by Department employees. The penalty for violation is summary discharge and it applies to the solicitor or recipient as well as the donor. ${ }^{84}$ Civilian personnel and officers on active duty are precluded from using their official titles in connection with any commercial enterprises or promotions. ${ }^{85}$ Outside employment is permitted but only to the extent that it does not interfere with official duties. Such activity must not reflect unfavorably on the government or place the individual concerned in a position of conflict. ${ }^{86}$

The Directive concludes with a summary of the new conflict of interest statute and the requirement that Department personnel be informed of existing standards of conduct at least twice a year.

\section{Organizational Conflicts}

One aspect of conflict of interest has not yet even been hinted at in the statutes, but the complexities of government contracting procedures especially in the fields of research and development have raised the possibility that there can be objectionable conflicts involving organizations as well as personnel. This problem was recognized officially in the Report to the President on Government Contracting for Research and Development, usually referred to as the Bell Report, ${ }^{87}$ and centers

${ }^{83}{ }_{18} 8$ U.S.C. $\$ 174 \mathrm{~d}\left(\mathrm{x}_{958)}\right.$ ). See p. $2 \mathrm{I2}$, supra.

${ }^{8 s}$ This prohibition also applies to the receipt of a gift from any employee being paid a salary less than the recipient and reflects the requirement of an old statute. Rev. Stat. $\$$ II3 (1875), 5 U.S.C. §II3 (1958).

${ }_{85}$ The Directive makes it clear that this rule does not limit the use of official titles on legitimate books and scholarly works.

${ }^{80}$ This clause also bans the use of enlisted members of the armed services for civil duties that are customarily performed by an available civilian work force. It further states that an active duty officer of the regular Navy or Marine Corps may not be employed by any person supplying naval supplies or war materials to the government and continue to receive his service pay.

${ }^{87}$ U.S. Bureau of the Budget, Report to the President on Government Contracting for Research and 
around the role of the contractor having system engineering or technical direction responsibility for work being performed under one or a series of contracts and his eligibility for future production work arising out of such contracts. The Department of Defense has addressed itself to this problem in a recent Regulation relating to organizational conflicts of interest. ${ }^{88}$ The stated objective of the Regulation is to prevent the existence of conflicting roles that might bias a contractor's judgment and to avoid placing any particular contractor in a position of unfair advantage over competitors. Four basic rules are laid down which are rather technical in nature:

I. If a contractor agrees to provide systems engineering and technical direction (SE/TD) for a system ${ }^{89}$ without at the same time assuming contractual responsibility for either (a) its development, (b) its integration, assembly and checkout (IAC), or (c) its production, that contractor shall not later be allowed to supply the system or any of its major components or to be a subcontractor or consultant to any other supplier of the system or its major components. The purpose of this rule is to avoid creating a situation in which the SE/TD contractor would be tempted to make engineering decisions favoring his own products and thus gain a competitive advantage during the production era.

2. If a contractor agrees to prepare and furnish complete specifications covering nondevelopmental items for use in competitive procurement, that contractor shall not be allowed to supply such items either as a prime or subcontractor during at least the initial procurement period and possibly longer, depending on the circumstances. This rule does not apply if the specification or data preparation is actually controlled by government representatives or in contracts for developmental items. The purpose of this rule is essentially the same as that of rule one. 3. If a single contractor who has not participated in the design or development of a system agrees to prepare the statement of work or related material to be used for competitive procurement, such contractor may not supply any of the services, the system or its major components unless he is the sole source. This situation generates the same problems as specifications covered in rule two.

4. If a contractor agrees to conduct studies or provide advice concerning a system

Development, SEN. Doc. No. 94,87 th Cong., 2 d Sess. (1962). This report was prepared by a committee of high government officials, including Robert S. McNamara, Secretary of Defense; James E. Webb, Administrator, National Aeronautics and Space Administration; John W. Macy, Jr., Chairman, Civil Service Commission; Glenn T. Seaborg, Chairman, Atomic Energy Commission; Alan T. Waterman, Director, National Science Foundation; Jerome B. Wiesner, Special Assistant to the President for Science and Technology; and with David E. Bell, Director, Bureau of the Budget as Chairman. This aspect of conflict had also been raised in several reports by congressional committees. Sec House Committec on Government Operations, Organization and Management of Missile Programs, Eleventh Report, H.R. REP. No. 1121, 86th Cong., Ist Sess. (1959); House Committee on Government Operations, Air Force Ballistic Missile Management, Formation of Aerospace Corporation, Third Report, H.R. REP. No. 324, 87th Cong., Ist Sess. (196I).

${ }_{88}$ Rules for the Avoidance of Organizational Conflicts of Interest, 28 Fed. Reg. 6449 (1963), also cited as Defense Directive 5500.10, June I, I963; ASPR I-I06.r, 32 C.F.R. $\$$ I.106-I (Supp. I963).

${ }^{89}$ A "system" can consist of a weapon system, communications system, or any other integrated device designed to perform a specific task. The Regulation defines "systems" to include subsystems, projects, or items. 
and the work requires access to the proprietary data of other companies, the contractor must agree to protect such data from unauthorized use and is not permitted to use the data as a supplier of the system or its components in procurements arising out of the study contract. This rule makes an important start in resolving problems arising out of the use of proprietary data on deffense contracts.

Left untouched by the new regulation was another area of possible conflict mentioned in the Bell Report that can involve non-profit organizations. The boards of directors (or trustees) of such organizations are often comprised of individuals having substantial commercial business interests. There is the possibility that the objectivity of such a non-profit organization with respect to some government contracts might be impaired by this fact.

The Atomic Energy Commission (AEC) has issued a regulation ${ }^{90}$ pertaining to the new conflict of interest statute that ties its implementation directly into the existing AEC organizational structure but otherwise closely resembles the Department of Defense Directive. Tight restrictions are placed on the appearances of former employees as attorneys or agents before AEC offices. Under such circumstances, the former employee is required to file in advance with the Commission a statement giving full particulars about the business he proposes to transact. If information on the form discloses any violation of post-employment restrictions imposed by Public Law 87-849, the General Counsel of AEC is authorized to take appropriate action.

\section{Ex Parte Communications}

Although not a procurement agency, the Securities and Exchange Commission (SEC) has isssued a recent regulation ${ }^{91}$ that pertains to one of the important peripheral areas of conflict of interest, ex parte communications. The regulation incorporates into the SEC Code of Behavior certain recommendations made by the Administrative Conference of the United States relating to ex parte communications. $^{92}$ It governs only such communications between outside persons and decisional personnel within SEC relating to certain "on the record"93 cases pending before the Commission. The regulation prohibits ex parte communications to designated Commission officers and employees from outside persons and bars the solicitation of such communications by SEC personnel. If an ex parte communication is

${ }^{00} 28$ Fed. Reg. 3439 (1963).

${ }^{01}$ Id. at 4446 .

${ }^{02}$ For the text of this recommendation, see Recommendation No. $x 6$, Administrative Conference of the United States, Selected Reports of the Administrative Conference of the United States Submitted by the Chairman of the Subcomm. on Administrative Practice and Procedure to the Senate Comm. on the fudiciary, S. Doc. No. 24 , 88th Cong., Ist Sess. (1963).

${ }^{03}$ Included in this category are proceedings in which an evidentiary hearing has been ordered such as revocation of the registration of an investment broker or adviser, review of an order of a registered national securities association expelling a member and action brought by SEC expelling or suspending a member from a registered national securities association, action under the Holding Company and Investment Company Acts in which no actual hearing has been ordered, and action to issue a stop order or suspend an exemption under the Securities Act. 
transmitted, the regulation requires that it be brought to the attention of all other parties to the proceeding to which it relates. Sanctions for breach of the rule are provided in the form of discipline or discharge in the case of SEC employees and suspension from practice before the Commission in the case of outsiders. In addition, violation may justify denial of the specific relief or benefit being sought in the particular proceeding.

This regulation is significant because it is probably the first recognition by a federal agency of the evils of ex parte communications. Such communications perform a role in conflicts of interest somewhat similar to that of money-they make it easier for outsiders to influence public officials to use their offices in an unfair manner. There is little doubt that the bar on ex parte communications will become more widespread as government agencies recast their policies in accommodating to the new ethical climate stimulated by Public Law $87-849$.

\section{Financtal InTERests}

For a number of years, certain federal agencies having responsibility in specific areas have required their officers and employees to divest themselves of all financial interests in those areas, or, sometimes in the alternative, to make full disclosure of such interests. ${ }^{94}$ The detailed requirements of section 208 of Public Law 87-849 make it necessary for government departments and agencies to define with considerable particularity just which types of financial interests are permitted and which are not. Several regulations have already been issued on this subject, ${ }^{95}$ and others are sure to follow. ${ }^{96}$

It is to be expected that there will be a considerable development and refinement of requirements and concepts relating to conflicts of interest on the part of government officials as implementing and interpretative regulations are issued on this subject by the various departments and agencies. One trend already noticeable is the tendency on the part of some agencies to apply the requirements of sections 203, 205, and 207 of Public Law $87-849$ to rule-making procedures in addition to the explicit transactions covered by those sections. ${ }^{97}$

\section{Retired Regular Officers}

The forgotten man in existing conflict of interest statutes is the retired regular officer of the armed forces and certain other uniformed services. ${ }^{98}$ The new laws

\footnotetext{
ox Typical examples would include the independent regulatory agencies such as Interstate Commerce Commission, Federal Aviation Agency, and Civil Aeronautics Board.

${ }^{95}$ See, for example, 28 Fed. Reg. 9288 (1963) (Tennessee Valley Authority); 27 id. 12612 (1962); 27 id. 5653 (1962); 28 id. 3021 (1963) (Small Business Administration); 27 id. 3812 (1962) (Dep't of the Interior).

${ }^{93}$ From present indications, it seems quite certain that government employees will be able to retain any investments they have in mutual funds except in the rare case where there might be the possibility of control over the management of the mutual fund's portfolio.

${ }_{97} 28$ Fed. Reg. 2707 (1963) (Civil Aeronautics Board); 28 Fed. Reg. ${ }_{3504}$ (1963) (Dep't of the Interior).

${ }^{88}$ These include the Public Health Service, Coast Guard, and Coast and Geodetic Survey.
} 
and regulations in this area do nothing but make life more complicated and risky for him.

It will be useful here to recapitulate the statutory application of Public Law $87-849$ to the various classifications of uniformed officer personnel in the government service.

(a) The term "regular government officer or employee" includes uniformed officers of the regular service on active duty who do not qualify as special government employees and uniformed officers in the reserve voluntarily on active duty who do not qualify as special government employees. Retired regular officers, retired reserve officers and reserve officers not on active duty do not become regular government officers or employees solely because of such officer status. They may, however, be performing government duties as civilians that bring them within the scope of this classification. Enlisted personnel of the uniformed services are not regular government officers or employees.

(b) The term "special government employee" includes uniformed officers of the regular service on active duty whose appointment is for a period not to exceed I30 days during any period of 365 consecutive days; uniformed officers of the reserve on voluntary active duty whose appointment is for a period not exceeding 130 days out of any period of 365 consecutive days; uniformed reserve officers on involuntary active duty regardless of the length of time; and reserve officers on active duty solely for training purposes..$^{99}$ Retired regular officers, retired reserve officers or retired reserve officers not on active duty do not become special government employees solely because of such officer status. Enlisted personnel of the uniformed services are not special government employees.

(c) The term "former officers and employees" includes officers of the uniformed services who formerly were classified as "regular government officers and employees" or "special government employees" and who have left the government service; retired regular officers; and reserve officers released from active duty. Enlisted personnel do not become former government officers or employees on retirement. A retired reserve officer is not by that fact alone a former government officer or employee. The only part of Public Law $87-849$ that applies to "former (government) officers and employees" is section $20 \%$, which covers postemployment restrictions.

(d) Retired officers of the uniformed services not on active duty and who are not otherwise officers or employees of the government are exempted from the application of sections 203 and 205 of the Act.

It can be seen that the only part of the basic conflicts statute that applies to retired inactive regular officers is section 207 relating to post-employment disqualification. If Public Law 87-849 had stopped there, much difficulty and discrimination relating

\footnotetext{
${ }^{\circ 0}$ Reserve officers may be classified as regular government officers or employees if their civilian occupation with the government gives them that status.
} 
to retired regular officers could have been avoided. But Congress left standing two of the old penal conflicts statutes to the extent that they apply to retired regular officers of the armed services. Section $28 \mathrm{I}$ of title eighteen ${ }^{100}$ permanently prohibits a retired regular officer from receiving or agreeing to receive any compensation for representing any person in the sale of anything to the government through the department in whose service he holds retired status. Section 283 of title eighteen ${ }^{101}$ imposes a two-year post-retirement ban on a retired regular officer acting as agent or attorney in the prosecution of any claim against the government if the claim involves the department in which he holds retired status or if it pertains to any subject matter with which he was directly connected while on active duty. This section also forbids giving any assistance in the prosecution of such claims and its sanctions apply whether or not compensation is received.

Old section $28 \mathrm{x}$ with its department-wide ban on representational selling activity goes far beyond the restraint philosophy of new section 207, and is, therefore, discriminatory. The prohibition of old section 283 is much more adequately covered in new section 207 so that retention of the old section was unnecessary. Sections $28 \mathrm{x}$ and 283 serve no useful purpose and should be repealed in their entirety.

Public Law $87-7777^{102}$ enacted just prior to Public Law $87-849$, repealed a longstanding discriminatory provision ${ }^{103}$ which prohibited retired regular Navy and regular Marine officers from selling or contracting for themselves or others with the Department of the Navy any time following their retirement, subject to forfeiture of retirement pay while so engaged. In its stead was substituted a revision of old section $59 \mathrm{c}$ of title five $\mathrm{e}^{104}$ which places all retired regular officers of the uniformed services ${ }^{105}$ on an even level and prohibits them for a period of three years after retirement from engaging in selling, ${ }^{106}$ contracting or negotiating the sale of war materials or supplies on behalf of themselves or others to any agency of the Department of Defense, Coast Guard, Coast and Geodetic Survey, and Public Health Service. ${ }^{107}$ The penalty for violation of this law is withholding of retirement pay

100 I8 U.S.C. $\$ 28 \mathrm{2}$ (1958).

${ }^{101}$ I8 U.S.C. $\$ 283$ (1958).

${ }^{102} 76$ Stat. 777,37 U.S.C. $\$ 8$ orc (Supp. IV, 1962).

${ }^{103}$ 10 U.S.C. $\$ 6 \mathrm{Ir2}(\mathrm{a})$ (1958). This law was discriminatory because it had no similar application to retired Army or Air Force officers.

${ }^{104} 67$ Stat. 437 (I953), 5 U.S.C. $\$ 59$ (c) (I958).

105 This classification covers retired officers of the Regular Army, Regular Navy, Regular Marine Corps, Regular Air Force, Regular Coast Guard, Coast and Geodetic Survey, and Public Health Scrvicc. 100 "Selling" is defined by the statute to mean:

I. Signing a bid, proposal, or contract.

2. Negotiating a contract.

3. Contacting an officer or employee of any of the foregoing departments or agencies for the purpose of: obtaining or negotiating contracts, negotiating or discussing changes in specifications, price, cost allowances, or other terms of a contract, or settling disputes concerning performance of a contract.

4. Any other liaison activity with a view toward the ultimate consummation of a sale even though the actual contract therefor is subsequently negotiated by another person.

${ }^{107}$ The prohibition is all inclusive and applies, for example, to a retired regular Navy officer who within three years of retirement negotiates a contract for war materials with the Coast and Geodetic 
during the entire performance of any contract concerning which the breach occurred. ${ }^{108}$

Retired regular officers of the armed services are required to file a statement of employment with the department from which they have retired within thirty days after retirement. This form must be kept up to date by revisions when necessary. ${ }^{109}$

There is one other restriction on retired regular officers of the uniformed services that is indirectly related to conflict of interest. They are not allowed to receive total compensation from the government in excess of \$10,000 per year. ${ }^{110}$ This means that their retirement pay plus any salary they receive from the government cannot exceed $\$ 10,000$ annually. The effect of this provision is virtually to deny the services of retired uniformed officers to the government, and to restrict even further their post-employment opportunities. ${ }^{111}$

The special limitations on the post-retirement activities of retired regular officers seem unduly harsh. The extent of the restrictions on selling activity is not consistent among the various statutes, and there is a wide area of uncertainty as to the interpretation of the word "selling" as it may apply to any particular set of facts. Some of the prohibitions regarding representation by retired regular officers are plainly unnecessary. Restraints on post-retirement activities of retired regular officers are so severe and uncertain, that the recruitment of able officers into the armed services is being seriously hampered. It is to be hoped that Congress will soon correct some of these glaring inequities by repealing sections $28 \mathrm{I}$ and 283 of title eighteen altogether and by bringing the post-retirement limitations that apply to retired regular officers more closely into line with the corresponding restrictions applied to other federal officers and employees.

\section{Conclusions}

Public Law $87-849$ and its associated regulations represent a significant advance in the development of the law of conflict of interest at the federal government level.

Survey. Note that the term "war materials and supplies" is very broad and could be interpreted to mean almost any kind of goods. Pub. L. No. 87-777 also perpetuated a restriction that was formerly found in Io U.S.C. $\$ 6 \mathrm{Ir2}$ (b) (1958) applying only to regular Naval and Marine officers who have not yet retired. The subsection prohibits such regular officers from being employed by any person furnishing war materials and supplies to the government, and permits withholding of their service pay during such period, 37 U.S.C. $\$ 80 \mathrm{I}$ (b) (Supp. IV, I962). The abuse covered by this provision is now more adequately dealt with by $\S 209$ of Pub. L. No. $87-849$, 76 Stat. I125 ( 9662 ), I8 U.S.C.A. $\$ 209$ (Supp. 1963).

${ }^{108} 42$ Decs. Comp. Gen. 32 (I962). The Comptroller General is usually the arbiter of disputes arising under this statute because claims for retirement pay withheld at the institgation of any government agency must be made to him.

${ }^{100}$ Department of Defense Directive 5500.7, 28 Fed. Reg. 5666 (Ig63).

${ }_{110} 47$ Stat. 406 (I932), as amended, 5 U.S.C. $\$ 59$ (a) (1958). The provisions of this statute have been side-stepped in some special cases which have drawn the ire of congressional committees. See Report of the House Committee on Post Office and Civil Service, Contracting Out Government Responsibility for Administrative, Management and Other Services, H.R. REP. No. 688, 86th Cong., Ist Sess. (1959).

III There is also a dual payment provision that applies to all employees of the federal government, uniformed officers and civilian, which prohibits them from holding any other federal office for which compensation is paid if they presently hold a government position for which the annual compensation 
Many state and local governments are following the lead of Washington in enforcing a stricter code of ethics. It is ardently to be hoped that this upsurge in business morality will spread to private commercial enterprise.

During this important stage of development, it is highly desirable that the law evolve at a relatively uniform pace across the broad front of the entire government. There is no justification for saying that the Secretary of the Army should observe a higher standard of ethics than a Senator. Nor is there any reason for treating the post-employment situation of a retired Civil Service employee differently from that of a retired regular officer of the armed services. ${ }^{112}$ If ex parte communications are improper in one agency, they are wrong in all agencies that conduct adjudicative proceedings. There is no reason why the Federal Procurement Regulation that applies to non-defense agencies should not incorporate the same restraints against conflicts of interest as does the Armed Services Procurement Regulation. These two regulations can also be utilized to clarify some of the more obscure aspects of the new basic conflicts statute and to fill in some of its gaps in coverage.

It is often said, and a great body of evidence supports the contention, that morality cannot be legislated. Ethics are a reflection of moral attitudes. No code of ethics with respect to conflicts of interest or anything else will really work unless government officials are afforded a reasonable degree of economic independence. Great strides in this direction have been made in recent years, but the situation should be kept under close and constant study. Public administration has become so significant in virtually all areas of endeavor that in the long run we can afford nothing less than the best.

exceeds $\$ 2,500$. 50 Stat. 549 (1938), as amended, 5 U.S.C. $\$ 62$ (1958). The statute primarily affects civilian employees of the government, but does have some impact on retired regular officers.

${ }^{112}$ A recent opinion by the Court of Claims has advanced a theory on which such a distinction might be based that is of questionable validity. That court in Hooper v. United States (Ct. Cl. No. 212-6r, January 24, 1964) suggests that the retirement salary of a retired regular officer of the armed services is "not solely recompense for past services, but a means devised by Congress to assure his availability and preparedness in future contingencies." Even if this theory is accepted, it would not seem to justify the severe post-employment restraints that presently apply to retired regular officers. 